\title{
The influence of diabetes mellitus on the spectrum of uropathogens and the antimicrobial resistance in elderly adult patients with
} urinary tract infection Mario Bonadio*, Silvia Costarelli ${ }^{\dagger}$, Giovanna Morelli ${ }^{\dagger}$ and Tiziana Tartaglia ${ }^{\dagger}$

Address: Infectious Diseases Section, Department of Medicine, Ospedale S.Chiara, via Roma 56, 56100 Pisa, Italy

Email: Mario Bonadio* - m.bonadio@int.med.unipi.it; Silvia Costarelli - m.bonadio@int.med.unipi.it; Giovanna Morelli - m.bonadio@int.med.unipi.it; Tiziana Tartaglia - m.bonadio@int.med.unipi.it

* Corresponding author †Equal contributors

Published: 17 March 2006

BMC Infectious Diseases2006, 6:54 doi:10.1 186/147I-2334-6-54
Received: 19 July 2005

Accepted: 17 March 2006

This article is available from: http://www.biomedcentral.com/I47I-2334/6/54

(c) 2006Bonadio et al; licensee BioMed Central Ltd.

This is an Open Access article distributed under the terms of the Creative Commons Attribution License (http://creativecommons.org/licenses/by/2.0), which permits unrestricted use, distribution, and reproduction in any medium, provided the original work is properly cited.

\begin{abstract}
Background: The role of Diabetes mellitus (DM) in the etiology and in the antimicrobial resistance of uropathogens in patients with urinary tract infection has not been well clarified. For this reason we have evaluated the spectrum of uropathogens and the profile of antibiotic resistance in both diabetic and non diabetic patients with asymptomatic urinary tract infection (UTI).
\end{abstract}

Methods: Urinary isolates and their patterns of susceptibility to the antimicrobials were evaluated in 346 diabetics (229 females and 117 males) and 975 non diabetics (679 females and 296 males) who were screened for significant bacteriuria ( $\geq 10^{5} \mathrm{CFU} / \mathrm{mL}$ urine). The mean age of diabetic and non diabetic patients was respectively 73.7 yrs \pm I5 S.D. and $72.7 \pm 24(p=N S)$.

Results: Most of our patients had asymptomatic UTI. The most frequent causative organisms of bacteriuria in females with and without DM were respectively: $E$. coli $54.1 \%$ vs $58.2 \%(p=N S)$, Enterococcus spp $8.3 \%$ vs $6.5 \%(p=N S)$, Pseudomonas spp 3.9 vs $4.7 \%(p=N S)$. The most frequent organisms in diabetic and non diabetic males were respectively $E$. coli $32.5 \%$ vs $31.4 \%$ ( $p=N S)$, Enterococcus spp $9.4 \%$ vs $14.5 \%(p=N S)$, Pseudomonas spp $8.5 \%$ vs $17.2 \%(p=<0.02)$. A similar isolation rate of $E$. coli, Enterococcus spp and Pseudomonas spp was also observed in patients with indwelling bladder catheter with and without DM. No significant differences in resistance rates to ampicillin, nitrofurantoin, cotrimoxazole and ciprofloxacin of E. coli and Enteroccus spp were observed between diabetic and non diabetic patients.

Conclusion: In our series of patients with asymptomatic UTI (mostly hospital acquired), diabetes mellitus per se does not seem to influence the isolation rate of different uropathogens and their susceptibility patterns to antimicrobials.

\section{Background}

Diabetes mellitus (DM) has long been considered to be a predisposing factor for urinary tract infection (UTI). However, since the concept of significant bacteriuria was intro- duced the reported data on the prevalence of asymptomatic bacteriuria appear to be conflicting [1-3].

Many UTIs are asymptomatic, especially in women. Unlike men with or without diabetes (among whom sim- 
Table I: Prevalence of bacteriuria in diabetic women reported in a series of selected studies

\begin{tabular}{|c|c|c|c|c|c|c|}
\hline \multicolumn{7}{|c|}{ Prevalence of bacteriuria } \\
\hline \multirow[t]{2}{*}{ Reference $\mathrm{N}^{\circ}$ year } & \multicolumn{2}{|c|}{ Diabetics } & \multicolumn{2}{|c|}{ Non diabetic } & \multirow[t]{2}{*}{ reported $\underline{P \text { value }}$} & \multirow[t]{2}{*}{ Clinical features } \\
\hline & $\underline{N^{\circ} \text { of pts }}$ & $\underline{\text { Pacts with }}$ & $\underline{N^{\circ} \text { of pts }}$ & $\underline{\text { Pacts with }}$ & & \\
\hline 41959 & 41 & 29.3 & 41 & 22 & - & $\begin{array}{l}\text { Hospitalised } \\
\text { Asymptomatic }\end{array}$ \\
\hline 51966 & 128 & 18.8 & 114 & 7.9 & - & $\begin{array}{l}\text { Outpatients } \\
\text { Asymptomatic }\end{array}$ \\
\hline 61967 & 195 & 2.0 & \multicolumn{2}{|c|}{ n.a. } & - & $\begin{array}{l}\text { Schoolgirls } \\
\text { Asymptomatic }\end{array}$ \\
\hline 71974 & 152 & 15.8 & 152 & 4.6 & - & $\begin{array}{l}\text { Outpatiens } \\
\text { Asymptomatic }\end{array}$ \\
\hline 81984 & 92 & 15.2 & 91 & 11.0 & NS & $\begin{array}{l}\text { Outpatients, } \\
\text { Asymptomatic/ } \\
\text { symptomatic }\end{array}$ \\
\hline 91986 & 341 & 9.1 & 100 & 5.0 & $<0.001$ & $\begin{array}{l}\text { Outpatients } \\
\text { Asymptomatic }\end{array}$ \\
\hline 101990 & n.a. & 31.3 & n.a & 16.0 & $<0.05$ & $\begin{array}{l}\text { Outpatients } \\
\text { Asymptomatic }\end{array}$ \\
\hline 11992 & 147 & 17.7 & \multicolumn{2}{|c|}{ n.a. } & - & $\begin{array}{l}\text { Outpatients, } \\
\text { Asymptomatic }\end{array}$ \\
\hline 121993 & 239 & 6.3 & 236 & 3.4 & NS & $\begin{array}{l}\text { Outpatiens } \\
\text { Asymptomatic }\end{array}$ \\
\hline 131995 & 1072 & 7.9 & \multicolumn{2}{|c|}{ n.a. } & - & $\begin{array}{l}\text { Outpatiens } \\
\text { Asymptomatic }\end{array}$ \\
\hline 142000 & 636 & 26.0 & 153 & 6.0 & $<0.001$ & $\begin{array}{l}\text { Outpatients } \\
\text { Asymptomatic }\end{array}$ \\
\hline 152001 & 149 & 4.6 & 298 & 4.0 & NS & $\begin{array}{l}\text { Asymptomatic } \\
\text { outpatients with } \\
\text { gestational } \\
\text { diabetes }\end{array}$ \\
\hline 162004 & 176 & 18.8 & 146 & 18.5 & NS & $\begin{array}{l}\text { Outpatients } \\
\text { Asymptomatic }\end{array}$ \\
\hline 172005 & 363 & 9.6 & 350 & 2.9 & - & $\begin{array}{l}\text { Outpatients } \\
\text { Asymptomatic }\end{array}$ \\
\hline
\end{tabular}

ilar rates of UTI have been documented in most studies), several recent reports have noted a higher prevalence of asymptomatic bacteriuria among women with diabetes than among women without diabetes. However, other studies on asymptomatic outpatient diabetic women reported different results regarding the prevalence of bacteriuria [[4-17] table 1].

The most common cause of UTI in men and women with and without DM is E. coli. Some reports have noted that a lower proportion of UTIs is caused by this organism in diabetic patients as compared with age-matched non diabetic patients [12,18-21]. Antimicrobial resistance among uropathogens causing community and hospital acquired urinary tract infections is increasing [22]. Few data are available on the role of DM itself as a risk factor for the development of antimicrobial resistance of the uropathogens.
For over 10 years our unit has been involved in a program dedicated to the epidemiological surveillance of both symptomatic and asymptomatic urinary tract infections. Particularly, the local trends of the causative agents of urinary infections and their resistance patterns to the antimicrobials are being monitored. For this reason we have undertaken a study to evaluate the spectrum of the etiologic agents and their profiles of antimicrobial resistance on a large series of diabetic and non diabetic patients with UTI.

\section{Methods}

Between March 1996 and June 2003, 10221 patients who were over the age of fifthy ( 6708 females and 3513 males) who were admitted to the department of medicine of the Pisa University-Hospital, were screened for asymptomatic bacteriuria (ASB). Out of the total studied population $1321(12.9 \%)$ patients showed ASB. The criterion used for 


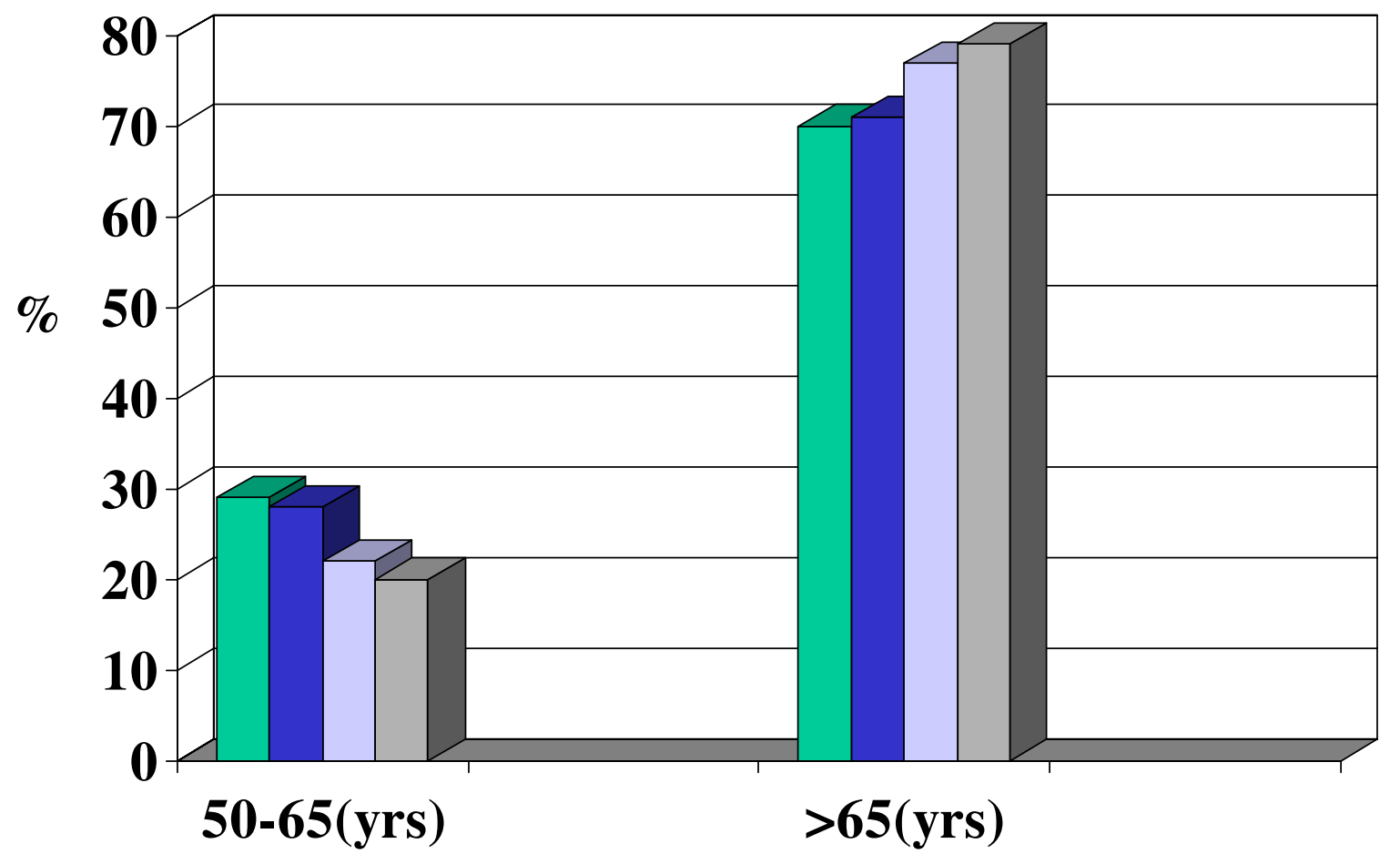

$\square$ non diabetic females $\square$ diabetic females $\quad \square$ non diabetic males $\square$ diabetic males

\section{Figure I}

Distribution (\%) of diabetic and non diabetic patients with urinary infection according to gender and age. Department of medicine, Pisa (1996-2003).

defining asymptomatic bacteriuria was the presence of at least $10^{5} \mathrm{CFU} / \mathrm{ml}$ in 1 culture of clean-voided mid-stream urine specimen or obtained by urethral catheterisation.

Regarding the patients with ASB, urine samples were obtained by clean voided mid-stream technique in 1066 patients and by urethral catheter in 255 patients with an indwelling bladder catheter. All of the patients were admitted to the department of medicine of the hospital of Pisa as inpatients. One- hundred and fifty patients were transfered from surgical or urologic wards. One year prior to admittance 320 patients had a history of urethral catheterisation. Three-hundred-forty-six patients were diabetic (117 males and 229 females) and 975 non diabetic (296 males and 679 females).
Quantitative urine culture was performed using a dipslide method; urine was also streaked on MacConkey agar. After an incubation at $37^{\circ} \mathrm{C}$ for $24 \mathrm{~h}$, the microrganisms were identified by standard biochemical tests. In vitro susceptibility to antibiotics was performed by an agar diffusion method (Kirby Bauer) employing dried filter paper discs impregnated with specific concentration of antimicrobial agents in according to the National Committee for the Clinical Laboratory Standards. (Performance Standards for Antimicrobial Testing. Wayne, PA: NCCLS, 1995). All the patients with UTI were interviewed by the authors on the basis of a specific questionnaire in order to know their age, gender, presence or absence of symptoms of UTI.

The criteria used to exclude possible diabetic patients from non diabetic group was to make sure that they had a 
Table 2: Isolation rate of uropathogens in male patients with and without diabetes. Department of Medicine, Pisa (1996-2003)

\begin{tabular}{lccccc}
\hline & \multicolumn{2}{c}{ Diabetic males } & \multicolumn{2}{c}{ Non diabetic males } \\
\hline & $N^{\circ}$ & $\%$ & $N^{\circ}$ & $\%$ & P value \\
\hline E. coli & 38 & 32.5 & 93 & 31.4 & NS \\
Enterococcus spP & 11 & 9.4 & 42 & 14.5 & NS \\
Pseudomonas spP & 10 & 8.5 & 51 & 17.2 & 0.02 \\
Other & 58 & 49.5 & 110 & 37.2 & NS \\
Total & 117 & 100 & 296 & 100 & \\
\hline
\end{tabular}

negative diabetic history and absence of glycosuria and fasting blood sugar less than $126 \mathrm{mg} / \mathrm{dl}$.

The statistical analysis of the results was carried-out using $\mathrm{X}^{2}$ test.

The research was conducted according to the Helsinki Declaration and was approved by the local ethic committee. Furthermore, all patients were informed about the aim of the study and their consent was obtained.

\section{Results}

In the period between 1996 and 2003, 1321 (12.9\%) out of 10221 patients (all older than 50 yrs;) who were admitted to the department of medicine of Pisa General hospital were found to have significant bacteriuria. Most of them had asymptomatic bacteriuria.

The rate of ASB was $12.76 \%$ (117 out of 917) and $11.4 \%$ (296 out of 2596) respectively in diabetic and non diabetic males. The rate of ASB was 14.97\% (229 out of 1529 ) and $13.1 \%$ (679 out of 5175) in diabetic and non diabetic females respectively.

Regarding the patients with ASB, 346 patients (229 females and 117 males), had a diagnosis of diabetes mellitus (90\% type II DM) and 975 (679 females and 296 males) were non diabetic patients. The mean HbA1c level of the diabetic patients at the time of admission was $7.8 \%$ $\pm 1.6 \mathrm{SD}$. The mean age of diabetic and non diabetic patients were respectively 73.7 yrs \pm 15 SD and $72.7 \pm 24$ $(\mathrm{p}=. \mathrm{NS})$. The distribution of the diabetic and non dia- betic patients with bacteriuria in according to the gender and age is represented in the figure 1 . No statistical differences were found between diabetics and non diabetics in the different groups of age and gender; Seventy-eight (22.5\%) out of 346 diabetics and 177 (18.1\%) out of 975 non diabetics had an indwelling bladder catheter respectively.

E. coli was the most frequent uropathogen isolated, and was responsible for UTI in $32.5 \%$ of diabetic and $31.4 \%$ of non diabetic males $(\mathrm{p}=\mathrm{NS})$. Enterococcus spp was isolated in $9,4 \%$ vs $14,5 \%(\mathrm{p}=\mathrm{NS})$, Pseudomonas spp was isolated in $8.5 \%$ vs $17.2 \%(\mathrm{p}=0.02)$ of diabetic and non diabetic patients respectively (Tab. 2). E. coli was more frequent in women (diabetics $54.1 \%$ and non diabetics $58.2 \%$ ) than in men (diabetics $32.5 \%$ and non diabetics $31.4 \%)$. The isolation rate of Enterococcus spp (8.3\% vs $6.5 \%$. p = NS) and Pseudomonas spp (3.9\% vs $4.7 \%$, p = NS) was also similar in diabetic and non diabetic women (Tab. 3).

The separate evaluation of women with symptomatic bacteriuria demonstrated, in both diabetic and non diabetic females with UTI, a similar frequency of the different strains (E. coli : $54 \%$ vs $58.2 \%, \mathrm{p}=\mathrm{NS}$, Enterococcus $\mathrm{spp}$ $8.3 \%$ vs $6.5 \%, \mathrm{p}=\mathrm{NS}$, Pseudomonas $\operatorname{spp} 3.9 \%$ vs $4.7 \%, \mathrm{p}=$ NS).

The rates of uropathogens in diabetic and non diabetics patients (males plus females) with indwelling bladder catheter were respectively: E. coli $30.8 \%$ vs $24.9 \%$, p = NS

Table 3: Isolation rate of uropathogens in female patients with and without diabetes. Department of Medicine, Pisa (1996-2003)

\begin{tabular}{lccccc}
\hline & \multicolumn{2}{c}{ Diabetic females } & \multicolumn{2}{c}{ Non diabetic females } \\
& $N^{\circ}$ & $\%$ & $N^{\circ}$ & $\%$ & P value \\
\hline E. coli & 124 & 54.1 & 395 & 58.2 & NS \\
Enterococcus spP & 19 & 8.3 & 44 & 6.5 & NS \\
Pseudomonas spp & 9 & 3.9 & 32 & 4.7 & NS \\
Other & 77 & 33.6 & 208 & 30.6 & NS \\
Total & 229 & 100 & 679 & 100 &
\end{tabular}


Table 4: Isolation rate of uropathogens in diabetic and non diabetic patients with indwelling bladder catheter. Department of Medicine, Pisa (1996-2003)

\begin{tabular}{|c|c|c|c|c|c|}
\hline & \multicolumn{2}{|c|}{ Diabetic patients with indwelling catheter } & \multicolumn{3}{|c|}{ Non diabetic patients with indwelling catheter } \\
\hline & $\mathrm{N}^{\circ}$ & $\%$ & $\mathrm{~N}^{\circ}$ & $\%$ & $P$ value \\
\hline E. coli & 24 & 30.8 & 44 & 24.9 & NS \\
\hline Enterococcus spp & 17 & 21.8 & 29 & 16.4 & NS \\
\hline Pseudomonas spp & 10 & 12.8 & 32 & 18.1 & NS \\
\hline Other & 27 & 34.6 & 72 & 40.0 & NS \\
\hline Total & 78 & 100 & 177 & 100 & \\
\hline
\end{tabular}

; Enterococcus spp 21.8\% vs $16.45 \%$, p = NS; Pseudomonas spp $12.8 \%$ vs $18.1 \%$, p = NS (Tab. 4 ).

The rates of antibiotic resistance of $E$. coli in diabetic vs non diabetic patients were : ampicillin 29\% vs 30.6\%, p = NS; cotrimoxazole $19.2 \%$ vs $17.4 \%, \mathrm{p}=\mathrm{NS}$; ciprofloxacin $11.6 \%$ vs $6.6 \%, \mathrm{p}=\mathrm{NS}$; nitrofurantoin $8.4 \%$ vs $6.9 \%, \mathrm{p}=$ NS (Tab. 5). The Pseudomonas strains isolated in diabetic and non diabetic patients had similar patterns of resistance against antipseudomonas drugs: ciprofloxacin 50\% vs $55.4 \%$, p = NS; ceftazidime $41.1 \%$ vs $14.1 \%, \mathrm{p}=\mathrm{NS}$ : imipenem $16.6 \%$ vs $11.1 \%, \mathrm{p}=\mathrm{NS}$; amikacin $16.6 \%$ vs $14.6 \%, \mathrm{p}=\mathrm{NS}$.

\section{Discussion}

In this study we have tried to determine whether there are differences in the bacteriologic patterns of UTI and in the antibiotic sensitivity patterns of the pathogens concerned with diabetic and non-diabetic patients. The study was carried-out on a large series of elderly adult diabetic and non diabetic patients admitted to the medical wards. More than $70 \%$ of the patients were older than 65 yrs of age. The age and the gender were absolutely comparable in both study populations as well as the proportion of patients with indwelling bladder catheter. The rate of $\mathrm{E}$. coli isolation we found in both diabetic and non diabetic patients was much lower than that usually observed in community acquired UTI, thus suggesting that a significant part of our patients had nosocomial acquired UTI.
Other studies have found that urinary Klebsiella is more frequent in patients with DM than in non diabetic patients [22-24].

Some authors have defined UTI in patients with DM as complicated when the UTI is symptomatic $[23,24]$. The spectrum of uropathogens we found in our patients and patterns of antimicrobial resistance in both DM and non DM patients are similar to those observed in other studies dealing with complicated UTI's. This finding can be explained by the fact that $20 \%$ of our patients had an indwelling bladder catheter. In addition many of our patients may have undergone previous antimicrobial treatment.

When our patients with indwelling catheter were considered separately, the rate of the different uropathogens did not differ significantly in diabetic and non diabetic groups. The spectrum of uropathogens and antimicrobial pattern resistance we found in our series of patients with catheter associated UTI may be different from those observed in other hospitals. This may depend on the different policy of antibiotics used in the various hospitals.

It is interesting to note that in a clinical setting different from ours, urinary isolates of symptomatic ambulatory postmenopausal women did not show a significant difference in the bacterial species when compared to a matched group of women without DM [25]. We observed a higher isolation rate of Pseudomonas spp in non diabetic than that

Table 5: Antimicrobial resistance of urinary E. coli in patients with and without diabetes. Department of Medicine, Pisa (1996-2003).

\begin{tabular}{|c|c|c|c|c|c|c|c|}
\hline \multirow{3}{*}{$\begin{array}{l}\text { Antomicrobial } \\
\text { agent }\end{array}$} & \multicolumn{3}{|c|}{ Diabetic patients } & \multicolumn{3}{|c|}{ Non diabetic patients } & \\
\hline & \multirow{2}{*}{$\begin{array}{c}\text { Tested strains } \\
n^{\circ}\end{array}$} & \multicolumn{2}{|c|}{ Resistant strains } & \multirow{2}{*}{$\begin{array}{c}\text { Tested strains } \\
n^{\circ}\end{array}$} & \multicolumn{2}{|c|}{ Resistant strains } & \multirow[b]{2}{*}{$P$ values } \\
\hline & & $n^{\circ}$ & $\%$ & & $\mathrm{n}^{\circ}$ & $\%$ & \\
\hline ampicillin & 157 & 46 & 29 & 490 & 147 & 39.6 & NS \\
\hline cotrimoxazole & 151 & 29 & 19.2 & 441 & 77 & 17.4 & NS \\
\hline ciprofloxacin & 154 & 18 & 11.6 & 463 & 31 & 6.6 & NS \\
\hline nitrofurantoin & 178 & 15 & 8.4 & 495 & 34 & 6.9 & NS \\
\hline
\end{tabular}


in diabetic males; therefore we must underline that many of our male non diabetic patients had a history of a previous instrumentation of the urinary tract.

Regarding the antimicrobial resistance profile of the uropathogens, we observed that the isolated E. coli strains were resistant at similar rates to ampicillin, cotrimoxazole, ciprofloxacin and nitrofurantoin in both diabetic and non diabetic patients. The high rate of $E$. coli resistance to ampicillin and cotrimoxazole we found in our series precludes, at least in our area, the choice of these or similar drugs in the empirical initial treatment of adult hospitalized patients with UTI. In a study performed in an emergency department, an association was found between the presence of cotrimoxazole resistance and diabetes, recent hospitalization and recent use of the same drug [26] but in an out-patients setting no correlation was found between $E$. coli resistance to cotrimoxazole $[27,28]$ or to quinolones and diabetes mellitus.

The proportion of Pseudomonas resistance to ciprofloxacin was very high as previously reported in our hospital but at a similar rate in patients with and without DM.

\section{Conclusion}

We found a low proportion of $E$. coli isolates (especially in men) in hospitalized elderly adult patients with asymptomatic UTI in both diabetics and non diabetics. In addition, the resistance of the uropathogens to the antibiotics was similar in patients with and without DM. These results confirm our previous observations obtained on a smaller size sample of patients with and without DM [29].

In our series of patients with asymptomatic UTI (mostly hospital acquired), diabetes mellitus could not be considered per se a risk factor for the emergence of a non E. coli organism and for antibiotic resistance.

\section{Competing interests}

The author(s) declare that they have no competing interests.

\section{Authors' contributions}

$\mathrm{MB}$ conceived of the study, coordinated the activity of the microbiology laboratory and the collection of clinical data and wrote the final draft.

SC cooperated in the collection of the clinical data, in the validation of the microbiologic results and performed the statistical evaluation.

GM cooperated in the collection of the clinical data and in the validation of the microbiologic results.
TT cooperated in the collection of the clinical data and in the validation of the microbiologic results.

All the authors read and approved the final manuscript.

\section{Acknowledgements}

The contribution of Marisa Baviello, medical student, in editing the manuscript is greatly appreciated

\section{References}

I. Rengards RT: Asymptomatic bacteriuria in sixty-eight diabetic patients. Am J Med Sci 1960, 239:159-64.

2. Szucs S, Cserhati, Csapo G, Balazs V: The relation between diabetes mellitus and infections of the urinary tract. Am J Med Sci 1960, 240:186-9|.

3. Andriole VT: Asymptomatic bacteriuria in patients with diabetes enemy or innocent visitor? N EnglJ Med 2002, 347:1617-8.

4. Huvos A, Rocha J: Frequency of bacteriuria in patients with diabetes mellitus. N Engl J Med 1959, 261:1213-6.

5. Vejsgaard R: Studies on urinary infections in diabetics. I. Bacteriuria in patients with diabetes mellitus and in control subjects. Acta Med Scand 1966, 179:173-82.

6. Pometta D, Rees SB, Younger D, Kass EH: Asymptomatic bacteriuria in diabetes mellitus. N Engl I Med 1967, 276: I I I8-2I.

7. OOi BS, Chen BT, Yu M: Prevalence and site of bacteriuria in diabetes mellitus. Postgrad Med J 1974, 50(586):497-9.

8. Bonadio M, Pulitanò L, Catania B, Marchetti P, Miccoli R, Navalesi R: Urinary tract infection in women with controlled diabetes. In Pyelonephritis Volume 5. Edited by: Losse H, Asscher AW, Lison AE, Andriole VT. Stuttgart, Germany: Georg Thieme Verlag; 1984: I09-13.

9. Schmitt JK, Fawcett CJ, Gullickson G: Asymptomatic bacteriuria and hemoglobin AI. Diabetes Care 1986, 9:518-20.

10. Kelestimur F, Unal A, Pasaoglu H, Basar E, Kilic H, Doganay M: Asymptomatic bacteriuria in patients with diabetes mellitus. Mikrobiyol Bul 1990, 24(2): 126-32.

II. Perez-Luque EL, de la Luz Villalpando M, Malacara JM: Association of sexual activity and bacteriuria in women with non.insulin dependent diabetes mellitus. J Diabetes Complications 1992, 6(4):254-57.

12. Brauner A, Flodin U, Hylander B, Ostenson C: Bacteriuria, bacterial virulence and host factors in diabetic patients. Diabet Med 1993, 10:550-554.

13. Zhanel GG, Nicolle LE, Harding GKM: Prevalence of asymptomatic bacteriuria and associated host factors in women with diabetes mellitus. The Manitoba Diabetic Urinary Infection Study Group. Clin Infect Dis 1995, 2 I (2):316-22.

14. Geerlings SE, Stolk RP, Camps MJ, Netten PM, Collet TJ, Hoepelman Al: Asymptomatic bacteriuria may be considered a complication in women with diabetes. The Diabetes Mellitus Women Asymptomatic Bacteriuria Utrecht Study Group. Diabetes Care 2000, 23:744-9.

15. Rizk DE, Mustafa N, Thomas L: The prevalence of urinary tract infections in patients with gestational diabetes mellitus. Int Urogynecol J 200I, I 2:317-322.

16. Bonadio M, Boldrini E, Forotti G, Matteucci E, Vigna A, Mori S, Giampietro O: Asymptomatic bacteriuria in women with diabetes: influence of metabolic control. Clin Infect Dis 38(6):e4 I-5. 2004 Mar 15, Epub 2004 Feb 27

17. Sotiropoulos A, Skourtis S, Merkouris P, Peppas T, Apostolou O, Kontela E, Skliros E, Pappas S: Incidence and outcome of asymptomatic bacteriuria in females with Type 2 diabetes mellitus over a I-year follow-up period and association with risk factors. Diabet Med 2005, 22(I I): 1625-6.

18. Patterson JE, Andriole VT: Bacterial urinary tract infections in diabetes. Infect Dis Clin North Am 1995, 9:25-5I.

19. Hansen DS, Gottschau A, Kolmos HJ: Epidemiology of Klebsiella bacteraemia: a case control study using Escherichia coli bacteraemia as control. J Hosp Infect 1998, 38: I 19-132.

20. Lee KH, Hui KP, Tan WC, Lim TK: Klebsiella bacteraemia: a report of 101 cases from National University Hospital, Singapore. J Hosp Infect 1994, 27:299-305. 
21. Lye WC, Chan RK, Lee EJ, Kumarasinghe G: Urinary tract infections in patients with diabetes mellitus. J Infect 1992, 24:169-174.

22. Bonadio M, Meini M, Spitaleri P, Gigli C: Current microbiological and clinical aspects of urinary tract infections. Eur Urol 200 I, 40(4):439-44.

23. Stapleton A: Urinary tract infections in patients with diabetes. Am J Med I I3(Suppl I A):80S-84S. 2002 Jul 8

24. Ronald $A$, Harding $G$ : Complicated urinary tract infections. Infect Dis Clin North Am 1997, I I:583-592.

25. Boyko EJ, Fihn SD, Scholes D, Chen CL, Normand EH, Yarbro P: Diabetes and the risk of acute urinary tract infection among postmenopausal women. Diabetes Care 2002, 25(10): 1778-83.

26. Wright SW, Wrenn KD, Haynes ML: Trimethoprim-sulfamethoxazole resistance among urinary coliform isolates. J Gen Intern Med 1999, 14:606-609.

27. Meiland R, Geerlings SE, De Neeling AJ, Hoepelman Al: Diabetes mellitus in itself is not a risk factor for antibiotic resistance in Escherichia coli isolated from patients with bacteriuria. Diabet Med 2004, 2 I (9): I032-4.

28. Steinke DT, Seaton RA, Phillips G, MacDonald TM, Davey PG: Factors associated with trimethoprim-resistant bacteria isolated from urine samples. I Antimicrob Chemother 1999, 43:84I-843.

29. Bonadio M, Meini M, Gigli C, Longo B, Vigna A: Urinary tract infections in diabetic patients. Urol Int 1999, 63:215-219.

\section{Pre-publication history}

The pre-publication history for this paper can be accessed here:

http://www.biomedcentral.com/1471-2334/6/54/prepub

Publish with Biomed Central and every scientist can read your work free of charge

"BioMed Central will be the most significant development for disseminating the results of biomedical research in our lifetime. "

Sir Paul Nurse, Cancer Research UK

Your research papers will be:

- available free of charge to the entire biomedical community

- peer reviewed and published immediately upon acceptance

- cited in PubMed and archived on PubMed Central

- yours - you keep the copyright 